\title{
MORPHO-ANATOMICAL CHANGES OF PEQUI LEAVES (Caryocar brasiliense Cambess.) EXPOSED TO SIMULATED DRIFT OF GLYPHOSATE ${ }^{1}$
}

Lailla Queiroz Silva ${ }^{2}$, Adriano Jakelaitis ${ }^{3 *}$, Sebastião Carvalho Vasconcelos Filho ${ }^{3}$, Alan Carlos Costa ${ }^{3}$ and Alana Cristina Ferreira Araújo ${ }^{4}$

\footnotetext{
${ }^{1}$ Received on 26.11.2014 accepted for publication on 24.06.2016.

${ }^{2}$ Instituto Federal de Educação, Ciência e Tecnologia Goiano, Mestrado em Ciências Agrárias - Agronomia, Rio Verde, GO - Brasil. E-mail: <lailla.queiroz@hotmail.com>.

${ }^{3}$ Instituto Federal de Educação, Ciência e Tecnologia Goiano, Diretoria de Pesquisa e Pós-Graduação, Campus de Rio Verde, Rio Verde, GO - Brasil.E-mail: <ajakelaitis@yahoo.com.br>, <sebastiao-vasconcelos@hotmail.com>and <alcarcos@gmail.com>.

${ }^{4}$ Instituto Federal de Educação, Ciência e Tecnologia Goiano, Graduando em Agronomia, Rio Verde, GO - Brasil. E-mail: $<$ alanashego@hotmail.com>.

*Corresponding author.
}

\begin{abstract}
The goal of this research was to examine phytotoxicity and leaf anatomy of pequi plants (Caryocar brasiliense Cambess.) exposed to simulated drift of glyphosate. The experimental design was randomized blocks with nine replications. Each experimental unit was composed by one 18-L pot with one plant. The treatments consisted of different doses of glyphosate sprayed: 0 (control), 50, 100, 250, 500, 1000 and $1500 \mathrm{~g}^{2} \mathrm{ha}^{-1}$ of glyphosate. Phytotoxicity visual ratings were carried out at 7, 14 and 21 days after spraying (DAS) by scores expressed in a percentage scale, within which zero and one hundred represent no symptom and plant death, respectively. Description of symptoms, changes in leaf anatomy and micromorphometric analysis were performed on leaves taken from plant top and middle third at 23 DAS. Poisoning symptoms were wilting, chlorosis followed by necrosis, winding of top leaves and leaf senescence, being intensified with increasing doses. Leaf anatomical changes were detected from the dose of $250 \mathrm{~g} \mathrm{ha}^{-1}$. The observed damages consisted of plasmolized cells, epidermal disruption, distorted cells, hyperplasia, cell collapsing, necrotic tissue and accumulation of phenolic compounds.
\end{abstract}

Keywords: Environmental pollution; Phytopoisoning; Tree species.

\section{ALTERAÇÕES MORFO-ANATÔMICAS DE FOLHAS DE PEQUI (Caryocar brasiliense Cambess.) SUBMETIDAS À DERIVA SIMULADA DE GLIFOSATO}

\begin{abstract}
RESUMO - O objetivo desta pesquisa foi avaliar a fitointoxicação e a anatomia foliar de plantas de pequi (Caryocar brasiliense Cambess.) submetidas à deriva simulada do glifosato. O delineamento utilizado foi em blocos casualizados com nove repetições. A unidade experimental foi constituída por um vaso, com capacidade de 18 litros, contendo uma planta. Os tratamentos corresponderam à aplicação das doses de 0 (controle), 50, 100, 250, 500, 1000 e $1500 \mathrm{~g}$ e.a. ha ${ }^{-1}$ de glifosato. Avaliações visuais de fitointoxicação foram realizadas aos 7, 14 e 21 dias após a aplicação (DAA) dos tratamentos por meio de notas expressas em escala percentual, em que zero e cem representaram ausência de sintomas e morte das plantas, respectivamente. Descrição dos sintomas, alterações na anatomia foliar e micromorfometria foram realizadas em folhas do ápice e do terço médio aos 23 DAA. Os sintomas visuais de intoxicação foram murcha, clorose seguida de necrose, enrolamento das folhas dos ápices e senescência foliar, sendo intensificadas com o aumento das doses. As alterações anatômicas nas folhas foram detectadas a partir da dose de $250 \mathrm{~g} \mathrm{ha} \mathrm{h}^{-1}$. Os danos causados foram células plasmolisadas, ruptura da epiderme, células alteradas, hiperplasia, células colapsadas, tecidos necrosados e acúmulo de compostos fenólicos.
\end{abstract}

Palavras-chave: Contaminação ambiental; Fitointoxicação; Espécie arbórea. 


\section{INTRODUCTION}

Pequi tree is a symbol of cerrado biome (savannahlike environment) being highlighted by its economical interest, mainly because of its fruit use in regional cuisine (ALMEIDA; SILVA, 1994) and for being major source of family income for farming communities (SANTOS et al., 2013). In Cerrado, changes brought about by expansion of the agricultural frontiers, meat and grain production increases for export have exhausted natural resources (BRASIL, 2009) jeopardizing native populations of pequi. The main threat to biodiversity in this system is the growth of agriculture and animal husbandry that is strengthened by an expressive use of chemical fertilizers, intensive mechanization and high-tech pesticides, among them, the herbicides (CUNHA et al., 2008).

Glyphosate is one of the nonselective herbicides most widely used worldwide in weed control due to their physicochemical and economic characteristics, besides its high agronomic efficacy, controlling a large number of weed species from mono- and eudicotyledon groups (SZEiKAiCS; DARVAS, 2012). Nevertheless, it has caused serious environmental problems by deposition out of the target of interest, due to drifting (FRANÇA et al., 2010; PEREIRA et al., 2010).

Pesticide drifting, especially herbicides, has been a current issue with significant losses to neighboring forest patches; therefore, it becomes crucial to detect it, identifying possible damages (BOUTIN et al., 2014). Injuring intensity and symptoms on non-target plants vary with several plant factors such as species, phenological stage and growing, besides weather conditions during application and the amount of active ingredient reaching the recipient plant (RIGOLI et al., 2008; PEREIRA et al., 2010).

Drift simulation researches with herbicides have enabled the assessment of plant injuries, growth drop or even death by glyphosate action (TUFFI SANTOS et al., 2009; HILZ; VERMEER, 2013; SCHRÜBBERS et al., 2014). The key visual symptoms after herbicide phytotoxicity are plant chlorosis followed by necrosis (FRANÇA et al., 2010). Phytotoxicity damages represent a quick way to identify sublethal effects on plant metabolism (WAGNER; MEROTTO JUNIOR, 2014), particularly whether they are seen on leaves, which respond rapidly to environmental changes through sudden changes in elongation rate and water relations (PASSIOURA; MUNNS, 2000).
Another important tool to detecting herbicide damages is leaf anatomical assessment that determines the easiness of product absorption, interception and retention; and helps to understand how each species forms a barrier against product penetration (COSTA et al., 2011).

Thus, the aim of this study was to assess phytotoxicity and anatomy of pequi leaves (Caryocar brasiliense Camb.) after exposure to a simulated drift of glyphosate.

\section{MATERIALAND METHODS}

The research was conducted in a climatized greenhouse at the Federal Institute of Education, Science and Technology of Goiás (IF Goiano) Campus in Rio Verde, GO, Brazil. The area is cartographically located at $17^{\circ} 48^{\prime} 67^{\prime \prime} \mathrm{S}, 50^{\circ} 54^{\prime} 18^{\prime \prime} \mathrm{W}$ and an altitude of 754 $\mathrm{m}$. Pequi seedlings (Caryocar brasiliense Camb.) were purchased from a nursery in the city of Guapo-GO, Brazil. Plants were selected by height, an average of $30 \mathrm{~cm}$, and subsequently transplanted to 18 -L pots. Each experimental unit consisted of one pot with one plant, totaling 63 plants.

The pots were filled with subsoil earth and fertilizer. The result of soil chemical analysis presented: $\mathrm{pH}$ in $\mathrm{CaCl}_{2}$ of $5.6 ; 22.84 \mathrm{mg} \mathrm{dm}^{-3}$ of $\mathrm{P} ; 190 \mathrm{mg} \mathrm{dm}^{-3}$ of $\mathrm{K}$; $5.98 \mathrm{cmolc} \mathrm{dm}^{-3}$ of Ca; $1.80 \mathrm{cmolc} \mathrm{dm}^{-3}$ of Mg; $2.80 \mathrm{cmolc}$ $\mathrm{dm}^{-3}$ of $\mathrm{H}+\mathrm{Al} ; 2.45 \mathrm{dag} \mathrm{kg}^{-1}$ of organic matter and $74.7 \%$ base saturation.

Substrate preparation was made with $100 \mathrm{~g} \mathrm{pot}^{-1}$ of single superphosphate and $20 \mathrm{~g} \mathrm{pot}^{-1}$ of potassium chloride. After transplanting, two grams of Forth Jardim ${ }^{\circledR}$ (N: 13; P2O5: 5; K2O: 13; B: 0.04; Ca: 1; Cu: 0.05; S: 5; Fe: 0.2; Mg: 1; Mn: 0.08; Mo: 0.005; Zn: 0.15\%, respectively) was added to each pot every 30 days. After 120 days, seedlings were again split by height for block standardization and, then, herbicide application.

Drift simulation consisted of glyphosate spraying (Roundup Transorb ${ }^{\circledR}, 480 \mathrm{~g} \mathrm{~L}^{-1}$ of acid equivalent) using a $\mathrm{CO} 2$ constant knapsack sprayer provided with four spray nozzles, flat jet type - XR11002 - VP (XRTeejet ${ }^{\circledR}$ ), with a spray volume of $120 \mathrm{~L} \mathrm{ha}^{-1}$. By the spraying time, plants were taken outside greenhouse, wherein wind speed was of $2.9 \mathrm{~m} \mathrm{~s}^{-1}$, maximum temperature of $18.3^{\circ} \mathrm{C}$ and relative humidity of $90 \%$. After application, pots were transferred back to the greenhouse, placing them in a randomized block arrangement with nine 
replications per treatment. The seven treatment corresponded to the glyphosate doses: 0 (Control), $50,100,250,500,1000$ and $1500 \mathrm{~g}$ ae ha ${ }^{-1}$.

Phytotoxicity assessments were carried out at 7, 14 and 21 days after spraying (DAS) through visual observation of each experimental unit, assigning scores from 0 to $100 \%$. Each score corresponded the degree of the symptoms, being from zero (no symptom) to 100 (plant death) (SBCPD, 1995). We also took pictures of the fully expanded leaves collected from plant top using a camera (Fujifilm FinePix machine, SL300®, São Paulo, Brazil); these samples were gathered at 23 DAS and aimed to depict visual damages caused by herbicide.

At 23 DAS, two fully expanded leaves were collected for anatomical analysis, detaching one from plant apex and another from the middle third (third internode), for each plant. Of each leaf, a portion of $25 \mathrm{~mm}^{2}$ was clipped from the middle part, containing the central vein. These sections were placed into test tubes, and covered, being fixed in Karnovsky solution (KARNOVSKY, 1965) for 24 hours. Subsequently, these samples were dehydrated in an ethanol series, preinfiltrated and infiltrated in historesin (Historesin Leica). Strips of 5-ìm thickness were cut along the leaf pieces with the aid of rotary microtome (Model 1508R). Afterwards, these strips were placed on histological slides, stained with blue toluidine - polychromatic staining at $0.05 \%$ in $0.1 \mathrm{M}$ phosphate buffer, at $\mathrm{pH}$ 6.8 (O’BRIEN et al., 1964), and permanent slides were mounted with Canada balsam.

Slide images were obtained from Olympus microscope (model BX61) via PD-72 camera. Hereupon, these pictures were used to measure micromorphometric variables, such as adaxial and abaxial epidermis heights, palisade and spongy parenchyma thickness and mesophyll width. These data were obtained by ImageJ software (Image Processing and Analysis in Java, version 1.47), making six observations per replicate, for each evaluation.

Both micromorphometric and phytotoxicity data underwent variance analysis (ANOVA) by $\mathrm{F}$ test, being adjusted to regression models at 5\% significance level. The ANOVA was carried out through statistical Assistat software, version 7.7 beta 2014 (SILVA; AZEVEDO, 2009) and graphical models were designed using Sigma Plot 9.0 software (SPSS Inc., USA).

\section{RESULTS}

Figure 1 shows that plant phytotoxicity was more intense as herbicide doses increased $(p<0.05)$ at 7,14 and 21 DAS. At 7 DAS, symptoms increased linearly up to the dose of $250 \mathrm{~g} \mathrm{ha}^{-1}$ glyphosate, which stabilized at higher doses, reaching an average of $10.5 \%$ phytotoxicity. At 14 and 21 DAS, simple linear models were fitted to phytotoxicity, meaning the injuries increased with higher doses reaching values close to $50 \%$ for the highest dose (1500 $\left.\mathrm{g} \mathrm{ha}^{-1}\right)$ compared to control in both times.

First, at 7 DAS, leaf wilting, severe chlorosis, winding and edge necrosis were observed on plants sprayed with high herbicide doses. The symptoms evolved to deformed apexes, advanced necrosis on leaf edges and sharp senescence, at 14 DAS. For the dose of 250 $\mathrm{g} \mathrm{ha}^{-1}$, chlorosis on the leaf edges were detected, and for higher doses, chlorosis and necrosis extended towards leaf edges, central vein and leaf tips (Figure 2).

Conversely, doses had no effect on some micromorphometric variables $(\mathrm{p}<0.05)$ as tissue thickness in the leaf middle third and apex (Figure 3), except for spongy parenchyma in the middle third (Figure 3-D). However, linear and nonlinear fit of the regression models was not possible. Such performance might be associated with a hormetic response as observed for spongy

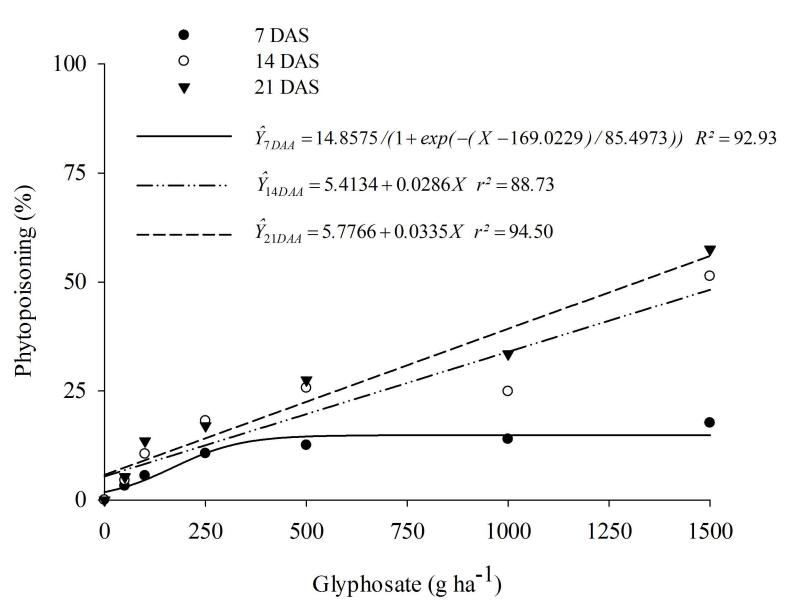

Figure 1 - Phytopoisoning in plants Caryocar brasiliense evaluated at 7, 14 and 21 days after spraying (DAS) in terms of rates of glyphosate.

Figura 1 - Fitointoxicação em plantas Caryocar brasiliense avaliadas aos 7, 14 e 21 dias após aplicação (DAS) em função das doses de glifosato.

Revista Árvore, Viçosa-MG, v.40, n.4, p.669-677, 2016

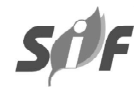




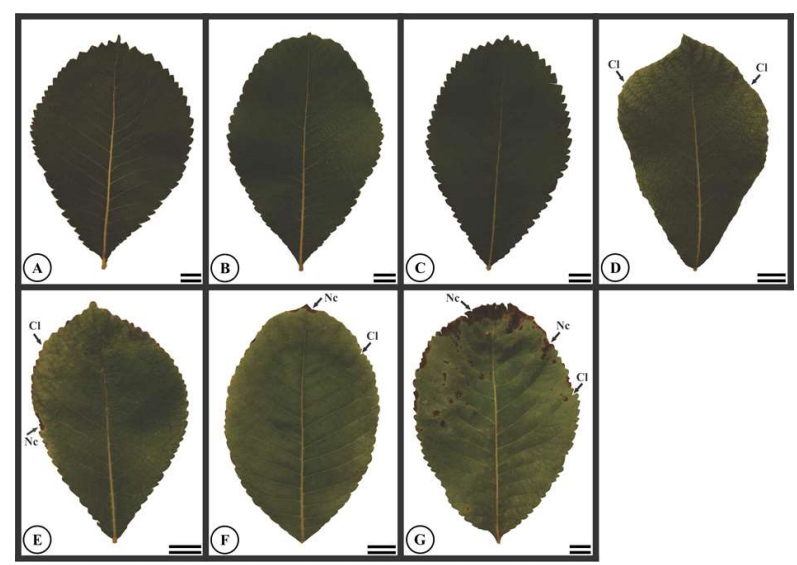

Figure 2 - Visual symptoms on leaves of Caryocar brasiliense in terms of rates of glyphosate. Capital letter corresponds to doses of glyphosate, which, A. Control, B. 50 C. 100 D. 250 E. 500 F. G. 1000 and $1500 \mathrm{~g} \mathrm{ha}^{-1} ; \mathrm{Cl}$. chlorosis and $\mathrm{Nc}$. necrosis; Bars $=2 \mathrm{~cm}$ to the right.

Figura 2 - Sintomas visuais em folhas de Caryocar brasiliense em função das doses de glifosato. Letras maiúsculas correspondem às doses de glifosato, onde, $A$. Controle, B. 50, C. 100, D. 250, E. 500, F. 1000 e G. $1500 \mathrm{~g} \mathrm{ha}^{-1}$; Cl. Clorose e Nc. Necrose; Barras a direita $=2 \mathrm{~cm}$.

parenchyma that increased in thickness at a dose of $50 \mathrm{~g} \mathrm{ha}^{-1}$ (Figure 3D).

Both sides of pequi leaves have simple epidermis and are hypo-stomatic with chlorenchyma of dorsoventral type (Figure 4 - A2 and B2) and collateral vascular bundle (Figure 4 - A1 and B1). On the adaxial surface, plasmolized cells were characterized (PC), at the apex and middle third (Figure 4 - C2, E2, G2, H2, I2 and M2) in xylem - apex and middle third (Figure 4 - C1, D1) in parenchymal cells - central vein (Figure 4 - G1) and in cortex parenchyma cells - the apex (Figure 4 - G1 and I1).

Epidermis ruptured $(*)$ on middle third and apex adaxial surfaces (Figure $4-$ F2, K2 and M2) and on the middle third (Figure 4-J2e N2). Altered cells (AC) by plasmolysis of the cortex parenchyma in the middle third were visualized (Figure 4 - F1). Figure 4 (H2) shows plasmolized parenchyma cells on the central vein, on the middle third portion and, at the apex of the leaves, hyperplasia in phloem (Figure 4 - J1) and in palisade and spongy parenchyma (Figure 4 - M2). Collapsed cells (CO) with rupture and cell compression at the apex were observed in xylem portion (Figure 4 - I1), in cortex parenchyma cells (Figure 4 - K1) and in phloem (Figure 4-M1); they were also observed in cortex parenchyma cells of the middle third (Figure $4-\mathrm{H} 1$, L1, L2 and N1).

Anatomical changes were sharper at the leaf apex, showing necrosis ( $\mathrm{Nc}$ ) between xylem and phloem (Figure 4 - G1), in spongy parenchyma (Figure 4 G2), parenchyma of central vein (Figure 4 - K1 and M1), in xylem (Figure 4 - M1), in palisade and spongy parenchyma (Figure 4 - K2 and M2). In the leaf middle third, such necrosis was observed between xylem and phloem (Figure 4 - J1) and parenchymal tissue along central vein (Figure 4 - L1, J2, N1 and N2).

In leaf apex, within vascular bundle region, phenolic compounds were detected mainly in cortex parenchyma cells (Figure 4-C1, E1, G1, I1, K1 and M1) and mesophyll (Figure $4-\mathrm{G} 2$, I2 and K2). Similar results were also observed for third internode leaves (Figure 4-D1, $\mathrm{H} 1, \mathrm{~J} 2$ and N2).

\section{DISCUSSION}

The use of pesticides, especially herbicides, has been promoting environmental and food contamination, people poisoning and problems associated with agricultural practices such as intoxication of further crops and emergence of herbicide-resistant weeds (BRITTO et al., 2012; NEVES; BELINI, 2013). Even so, literature reports concerning biodiversity impacts on surrounding areas are still scarce, especially on wind-drifted agrochemicals.

In plants, particularly leaves, symptom overview has been the main tool to assess damages by biotic and abiotic factors (TUFFI SANTOS et al., 2008). Similarly, another major tool is anatomical description as micromorphological changes precede onset of symptoms, showing thus significant additional data like invisible-to-the-naked-eye injuries (TUFFI SANTOS et al., 2009).

Glyphosate-toxicity symptoms in pequi plants were marked by chlorosis of young leaves, followed by edge necrosis, being intensified with increasing doses. According Rigoli et al., (2008) and Tuffi Santos et al. (2009), glyphosate is absorbed and then translocated mainly through phloem to meristematic tissues, being the first injuries reported in younger parts of the plant and extending then to older leaves, confirming the symptomatology described in this study. 

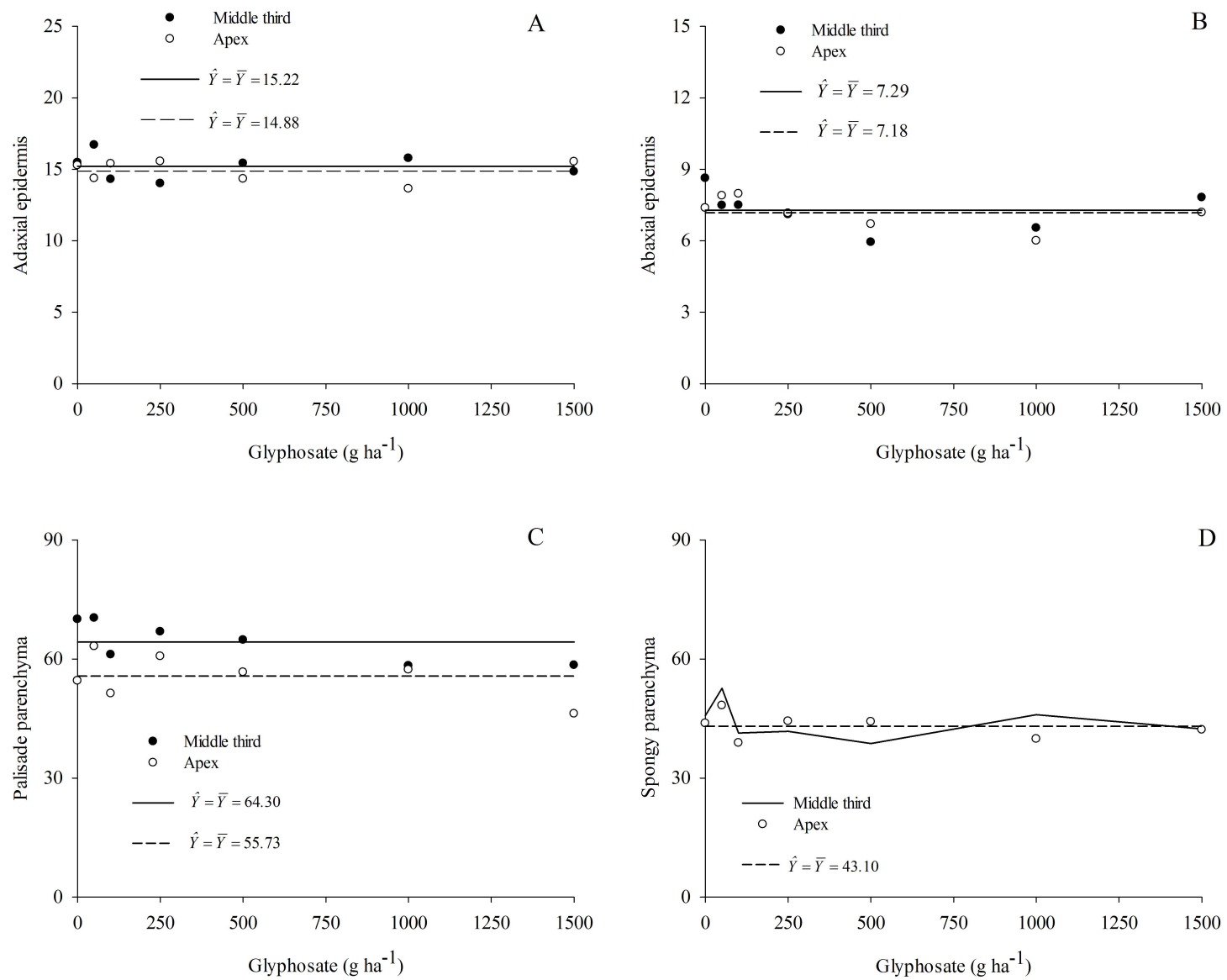

Figure 3 - Micromorphometrics the apex and middle third leaf tissues related to adaxial epidermis (A), abaxial (B), palisade parenchyma (C) spongy parenchyma (D) and mesophyll (E) of plants of Caryocar brasiliense in terms of rates of glyphosate. Measured in microns.

Figura 3 - Micromorfometria dos tecidos foliares referentes à epiderme adaxial (A), abaxial (B), parênquima paliçádico (C) parênquima esponjoso (D) e mesofilo (E) do terço médio e do ápice de plantas de Caryocar brasiliense em função de doses de glifosato. Medidos em $\mu \mathrm{m}$.

Duke and Powles (2008) have also reported that, although glyphosate first action site is on the shikimate pathway making aromatic amino acids unavailable, the first visual symptom is chlorosis in young leaves, thereupon necrosis. The shown chlorosis might be reflection of chloroplast deterioration or even inhibition of chlorophyll formation (FRANÇA et al., 2010; COSTA et al., 2012), or else $\mathrm{Mg}$ and $\mathrm{Mn}$ immobilization for chlorophyll formation (ZOBIOLE et al., 2011).

Even though symptoms were also observed for the lowest doses in the first week after spraying, no statistical differences were confirmed for most of the micromorphometric variables, except for spongy parenchyma thickness. According to Costa et al. (2009), damages and injuries by glyphosate drift to non-target plants depend on product concentration and quantity of active ingredient reaching on the site of action.

Nonetheless, glyphosate treated plants may undergo hormesis, which is plant growth stimulation by low doses of substances considered toxic. Cedergreen (2008) claimed that glyphosate is one of the herbicides which consistently induce such response, especially at doses below $60 \mathrm{~g} \mathrm{ha}^{-1}$. This performance could be observed in the increased thickness of the spongy parenchyma.

Revista Árvore, Viçosa-MG, v.40, n.4, p.669-677, 2016 


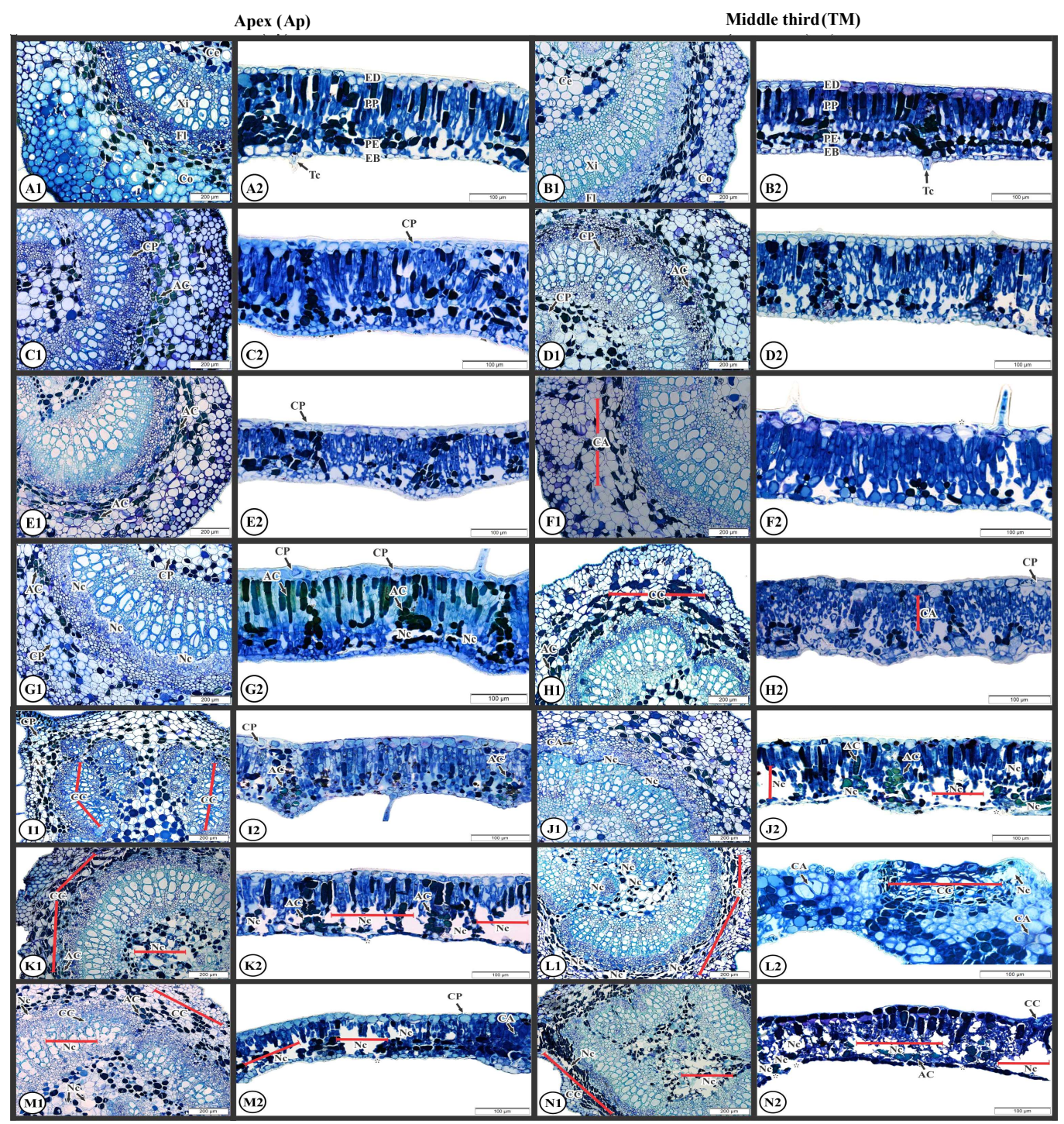

Figure 4 - Leaf anatomy of Caryocar brasiliense in terms of rates of glyphosate. Cut the leaves from the apex (Ap) and cut leaves from the middle third (TM). Number accompanying capitalized related to: 1. Region 2. Region vascular bundle and mesophyll; Capital letter corresponds to doses in $\mathrm{g} \mathrm{ha}^{-1}$, where A (Ap) and B (TM) Control, C (Ap) and D (TM) 50, E (Ap) and F (TM): 100, G (Ap) and H (TM): 250, I (Ap) and J (TM): $500 \mathrm{~K}$ (Ap) and L (TM) 1000, and M (Ap) and N (TM): 1500; Xi: Xylem; Fl: phloem; Ce: parenchymatous cells of the rib center; Co parenchyma cells of the cortex; ED: adaxial epidermis; EB: abaxial epidermis; PP: palisade parenchyma; PE: spongy parenchyma; Tc: Trichome; CP: plasmolized cells; AC: Accumulation of compounds; CA: altered cells; Nc: Necrosis; CC: collapsed cells; *: Disruption of wall.

Figura 4-Anatomia foliar de Caryocar brasiliense em função das doses de glifosato. Corte de folhas do ápice (Ap) e Corte de folhas do terço médio (TM). Número que acompanha letra maiúscula referente à: 1. Região do feixe vascular e 2. Região do mesofilo; Letra maiúscula corresponde às doses em g e.a. ha ${ }^{-1}$, onde, A (Ap) e B (TM) Controle, $C(A p)$ e D (TM): 50, E (Ap) e F (TM): 100, G (Ap) e H(TM): 250, I (Ap) e J (TM): 500, K (Ap) e L (TM): 1000 e M (Ap) e N (TM): 1500; Xi: Xilema; Fl: floema; Ce: Células parenquimáticas do centro da nervura; Co: Células parenquimáticas do córtex; ED: Epiderme adaxial; EB: Epiderme abaxial; PP: Parênquima paliçádico; PE: Parênquima esponjoso; Tc: Tricoma; CP: Células plasmolizadas; AC: Acúmulo de compostos; CA: Células alteradas; Nc: Necrose; CC: Células colapsadas; *: Rompimento de parede.

Revista Árvore, Viçosa-MG, v.40, n.4, p.669-677, 2016 
By contrast, increasing doses have brought harmful effects by glyphosate drift, raising the percentage of injuries in different crops, such as coffee plantations (FRANÇA et al., 2013), eucalyptus (PEREIRA et al., 2010) and jatropha (COSTA et al., 2009).

The occurrence of plasmolized cells, epidermis rupturing, collapsed cells, hyperplasia and necrotic tissue in pequi leaves treated with glyphosate corroborate the results observed by Tuffi Santos et al. (2008) in Eucalyptus grandis. In another survey conducted by Tuffi Santos et al. (2005), in eucalyptus treated with different doses of glyphosate, the authors reported necrotic areas, chlorenchyma cell and epidermis hyperplasia and collapse thereof.

For Marques et al. (2012), foliar anatomical structures like epidermis, vascular bundle, parenchyma, trichome and even leaf thickness may be associated to greater or lesser plant resistance to glyphosate, as well as to symptom description. Costa et al. (2011) stated that leaf anatomical analysis could be used to identifying susceptible, tolerant or resistant species to herbicides. Biomonitoring anatomical changes in pequi leaves can become an alternative to detect glyphosate contamination in forest patches near crops; in this regard, measurements of physiological and biochemical traits such as shikimic acid content is required.

\section{CONCLUSIONS}

Glyphosate can be phytotoxic to pequi trees at low doses. Poisoning symptoms shown in leaves are withering, chlorosis followed by necrosis, winding of top leaves and senescence, being intoxication intensified with increasing doses. Glyphosate also promotes leaf anatomical changes as cell plasmolysis, epidermal disruption, altered cells, hyperplasia, collapsed cells, necrotic tissues and accumulation of phenolic compounds.

Glyphosate-induced alterations can be used as indicators of herbicide phytotoxic action on the species C. brasiliense, since provided by specific biochemical tests.

\section{ACKNOWLEDGEMENTS}

The authors thank the CNPq by financial support through Public Call MCT/CNPq/MEC/CAPES - Ação Transversal $\mathrm{n}^{\circ}$ 06/2011 - Casadinho/Procad, and to the FINEP through Public Call MCT/FINEP/CT-INFRA - PROINFRA - 02/2010.

\section{REFERENCES}

Almeida, S.P.; SIlVA, J.A. Piqui e buriti: importância alimentar para a população dos cerrados. Planaltina: Embrapa-CPAC, 1994. p.38.

BOUTIN, C.; STRANDBERG, B.; CARPENTER, D.; MATHIASSEN, S.K.; THOMAS, P.J. Herbicide impact on non-target plant reproduction: What are the toxicological and ecological implications?

Environmental Pollution, v. 185, p.295-306, 2014.

BRASIL. Ministério do Meio Ambiente.

Relatório Técnico de Monitoramento do Desmatamento no Bioma Cerrado, 2002 a 2008: Dados Revisados. Novembro, 2009

BRITTO, F.B.; VASCO, A.N.; PEREIRA, A.P.S.; MÉLLO JÚNIOR, A.V.; NOGUEIRA, L.C. Herbicidas no alto rio Poxim, Sergipe e os riscos de contaminação dos recursos hídricos. Revista Ciência Agronômica, v.43, n.2, p.390-398, 2012.

CEDERGREEN, N. Is the growth stimulation by low doses of glyphosate sustained over time?

Environmental Pollution, v.156, p.10991104, 2008.

COSTA, A.C.P.R.; COSTA, N.V.; PEREIRA, M.R.R.P.; MARTINS, D. Efeito da deriva simulada de glyphosate em diferentes partes da planta de Eucalyptus grandis. Semina: Ciências Agrárias, v.33, n.5, p.1663-1672, 2012.

COSTA, N.V.; ERASMO, E.A.L.; QUEIROZ, P.A.; DORNELAS, D.F.; DORNELAS, B.F. Efeito da deriva simulada de glyphosate no crescimento inicial de plantas de pinhão-manso. Planta Daninha, v.27, p.1105-1110, 2009.

COSTA, N.V.; MARTINS, D.; RODELLA, R.A.; RODRIGUES-COSTA, A.C.P. Alterações anatômicas foliares em Eichhornia crassipes submetidas à aplicação de herbicidas. Planta Daninha, v.29, n.1, p.17-23, 2011.

CUNHA, N.R.S.; LIMA, J.E.; GOMES, M.F.M.; BRAGA, M.J. A intensidade da exploração agropecuária como indicador da degradação ambiental na região dos Cerrados, Brasil. 
Piracicaba/SP. Revista de Economia e Sociologia Rural, v.46, n.2, p.291-323, 2008.

DUKE, S. O.; POWLES, S. B. Glyphosate: a oncein-a-century herbicide. Pesticide

Management Science, v.64, p.319-325, 2008.

FRANÇA, A.C.; CARVALHO, F.P.; FIALHO, C.M.T.; D’ANTONINO, L.; SILVA, A.A.; SANTOS, J.B.; FERREIRA, L.R. Deriva simulada do glyphosate em cultivares de café Acaiá e Catucaí. Planta Daninha, v. 31, n.2, p.443$451,2013$.

FRANÇA, A.C.; FREITAS, M.A.M.; FIALHO, C.M.T.; SILVA, A.A.; REIS, M.R.; GALON, L.; VICTORIA FILHO, R. Crescimento de cultivares de café arábica submetidos à doses do glyphosate. Planta Daninha, v.28, n.3, p.599$607,2010$.

HILZ, E.; VERMEER, E.W.P. Spray drift review: The extent to which a formulation can contribute to spray drift reduction. Crop Protection, v.44, p.75-83, 2013.

KARNOVSKY, M.J. A formaldehydeglutaraldehyde fixative of high osmolarity for use in electron microscopy. Journal of Cell Biology, v.27, p.137-138, 1965.

MARQUES, R.P.; RODELLA, R.A.; MARTINS, D. Características da anatomia foliar de espécies de braquiária e sua relação com a sensibilidade a herbicidas. Planta Daninha, v.30, n.4, p.809816,2012

NEVES, P.D.M.; BELINI, M. Intoxicações por agrotóxicos na mesorregião norte central paranaense, Brasil - 2002 a 2011. Ciência \& Saúde Coletiva, v. 18, n.11, p.3147-3156, 2013

O'BRIEN, T.P.; FEDER, N.; McCULLY, M.E. Polychromatic staining of plant cell walls by toluidine blue O. Protoplasma, v. 59, n.2, p.368-373, 1964.

PASSIOURA, J.B.; MUNNS, R. Rapid environmental changes that affect leaf water status induce transient surges or pauses in leaf expansion rate. Australian Journal of Plant Physiology, v.27, n.10, p.941-948, 2000

PEREIRA, M.R.R.; RODRIGUES, A.C.P.; COSTA, N.V.; MARTINS, D.; KLAR, A.E.; SILVA, M.R.

Revista Árvore, Viçosa-MG, v.40, n.4, p.669-677, 2016
Efeito da deriva de glyphosate sobre algumas características fisiológicas em plantas de eucalipto. Interciencia, v.35, n.4, p.279-281, 2010.

RIGOLI, R.P.; FONTANA, L.C.; FIGUEREDO, S.S.; NOLDIN, J.A. Resposta de plantas de beterraba (Beta vulgaris) e de cenoura (Daucus carota) à deriva simulada de glyphosate e clomazone. Planta Daninha, v.26, n.2, p.451456, 2008.

SANTOS, F.S.; SANTOS, R.F.; DIAS, P.P.; ZANÃO JR., L.A.; TOMASSONI, F. A cultura do Pequi (Caryocar brasiliense Camb.). Acta Iguazu, v.2, n.3, p.46-57, 2013.

\section{SOCIEDADE BRASILEIRA DA CIÊNCIA DAS} PLANTAS DANINHAS - SBCPD.

Procedimentos para instalação, avaliação e análise de experimentos com herbicidas. Londrina: 1995. p.42.

SCHRÜBBERS, L.C.; VALVERDE, B.E.; SORENSEN, J.C.; CEDERGREEN, N. Glyphosate spray drift in Coffea arabica - Sensitivity of coffee plants and possible use of shikimic acid as a biomarker for glyphosate exposure.

Pesticide Biochemistry and Physiology. v.115, p.15-22, 2014.

SILVA, F.A.; AZEVEDO, C.A.V. Principal components analysis in the software AssistatStatistical attendance. In: WORLD CONGRESS ON COMPUTERS IN AGRICULTURE, 7., 2009, Reno. Proceedings... Reno: American Society of Agricultural and Biological Engineers, 2009.

SZEiKAiCS, A.; DARVAS, B. Forty years with glyphosate. In: HASANEEN, M.G. (Ed.).

Herbicides - properties, synthesis and control of weeds. Rijeka: InTech, 2012. p.247-284.

TUFFI SANTOS, L.D.; FERREIRA, F.A.; MEIRA, R.M.S.A.; BARROS, N.F.; FERREIRA, L.R.; MACHADO, A.F.L. Crescimento e morfoanatomia foliar de eucalipto sob efeito de deriva do glyphosate. Planta Daninha, v.23, n.1, p.133-142, 2005.

TUFFI SANTOS, L.D.; SANT'ANNA-SANTOS, B.F.; MEIRA, R.M.S.A.; FERREIRA, F.A.; TIBURCIO, R.A.S.T.; SILVA, E.C.F. Micromorfologia foliar na análise da fitotoxidez 
por glyphosate em Eucalyptus grandis. Planta Daninha, v.27, n.4, p.711-720, 2009.

TUFFI SANTOS, L.D.; SANT'ANNA-SANTOS, B.F.; MEIRA, R.M.S.A.; TIBURCIO, R.A.S.; FERREIRA, F.A.; MELO, C.A.D.; SILVA, E.F.S. Danos visuais e anatômicos causados pelo glyphosate em folhas de Eucalyptus grandis. Planta Daninha, v.26, n.1, p.9-16, 2008.

WAGNER, J.F.; MEROTTO JUNIOR, A. Parâmetros fisiológicos e nutricionais de cultivares de soja resistentes ao glifosato em comparação com cultivares isogênicas próximas. Ciência Rural, v.44, n.3, p.393399, 2014.

ZOBIOLE, L.H.S.; KREMERB, R.K.; OLIVEIRA JR, R.S.; CONSTANTIN, J. Glyphosate affects chlorophyll, nodulation and nutrient accumulation of "second generation" glyphosate-resistant soybean (Glycine max L.). Pesticide Biochemistry and Physiology, v.99, n.1, p.53-60, 2011. 